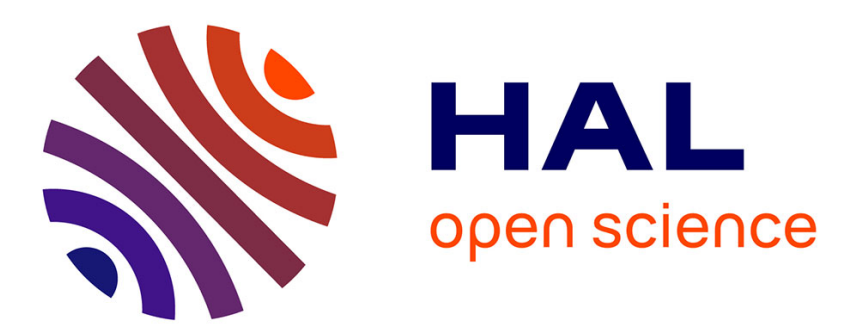

\title{
Voltage oscillations in Single-Chamber Fuel Cells operating under a C3H8/O2 mixture
}

Geoffroy Gadacz, Jean-Paul Viricelle, Christophe Pijolat, Michèle Pijolat

\section{To cite this version:}

Geoffroy Gadacz, Jean-Paul Viricelle, Christophe Pijolat, Michèle Pijolat. Voltage oscillations in Single-Chamber Fuel Cells operating under a C3H8/O2 mixture. Fuel Cells, 2013, 13 (6), pp.10321039. 10.1002/fuce.201300165 . emse-00958519

\section{HAL Id: emse-00958519 https://hal-emse.ccsd.cnrs.fr/emse-00958519}

Submitted on 18 Mar 2014

HAL is a multi-disciplinary open access archive for the deposit and dissemination of scientific research documents, whether they are published or not. The documents may come from teaching and research institutions in France or abroad, or from public or private research centers.
L'archive ouverte pluridisciplinaire $\mathbf{H A L}$, est destinée au dépôt et à la diffusion de documents scientifiques de niveau recherche, publiés ou non, émanant des établissements d'enseignement et de recherche français ou étrangers, des laboratoires publics ou privés. 


\title{
Voltage Oscillations in Single-Chamber Fuel Cells operating under a $\mathrm{C}_{3} \mathrm{H}_{8}$ /
}

\author{
$\mathrm{O}_{2}$ mixture.
}

Geoffroy Gadacz, Jean-Paul Viricelle, Christophe Pijolat, Michèle Pijolat

Ecole Nationale Supérieure des Mines

SPIN-EMSE, CNRS:UMR5307, LGF, 158 Cours Fauriel, F42023 Saint-Etienne Cedex 2. Corresponding author : Jean-Paul Viricelle, viricelle@emse.fr

Phone : 33477420252

Abstract : Single-Chamber Fuel Cells (SCFC) are an alternative way to conventional SOFCs. Effectively, they do not require any more sealing between anodic and cathodic compartment's as the cell is fed with a mixture of hydrocarbon and oxygen. This paper deals with voltage oscillations observed with a SCFC composed of GDC $\left(\mathrm{Ce}_{0.9} \mathbf{G d}_{0.1} \mathrm{O}_{1.95}\right)$ supported electrolyte, Ni-GDC anode and a BSCF $\left(\mathrm{Ba}_{0.5} \mathrm{Sr}_{0.5} \mathrm{Co}_{0.8} \mathrm{Fe}_{0.2} \mathrm{O}_{3-\delta}\right)$ cathode, operating in the temperature range $500-600^{\circ} \mathrm{C}$ and under various propane and oxygen mixtures, with a $\mathrm{C}_{3} \mathrm{H}_{8} / \mathrm{O}_{2}$ ratio between 0.2-0.66 . Electrical and Thermo-Programmed Oxidation (TPO) measurements combined with SEM observations allowed us proving that these oscillations are due to carbon nanowires deposition/oxidation cycles. A mechanism is proposed to explain this behaviour.

Keywords: Single Chamber Fuel Cell, Propane, Oscillation, Anode.

\section{Introduction}

Solid Oxide Fuel Cells have been intensively studied in the two past decades [1-3]. One of the biggest challenges is to control the sealing procedure [4]. Alternatives Fuel Cells such as 
Single Chamber Fuel Cells (SCFC) have been proposed early in the 90ties by the group of Hibino [5-6] who has performed the most significant developments at this period. Since this date, SCFC have shown a growing interest and many other research groups have focussed on this kind of device as reported in recent review papers [7-8]. Their main working principle is reminder hereafter. In such devices, anode and cathode are directly exposed to an oxygen and hydrocarbon mixture. The cathode must be highly selective to the oxygen adsorption, without direct catalytic activity for hydrocarbon conversion [9]. The anode, which is generally composed of a nickel based cermet, produces hydrogen and carbon monoxide (partial oxidation of the hydrocarbon) that maintains a reducing atmosphere inside the anode [10], as presented by reaction Eq.(1).

$$
\mathrm{C}_{x} \mathrm{H}_{y}+\frac{x}{2} \mathrm{O}_{2} \rightarrow x \mathrm{CO}+\frac{y}{2} \mathrm{H}_{2}
$$

A lot of other reactions are also known to take place at the anode, such as total oxidation of the hydrocarbon Eq. (2), direct oxidation of hydrogen Eq. (3), or direct oxidation of carbon monoxide Eq. (4).

$$
\begin{gathered}
\mathrm{C}_{x} \mathrm{H}_{y}+\left(x+\frac{y}{4}\right) \mathrm{O}_{2} \rightarrow x \mathrm{CO}_{2}+\frac{y}{2} \mathrm{H}_{2} \mathrm{O} \\
\mathrm{H}_{2}+\frac{1}{2} \mathrm{O}_{2} \rightarrow \mathrm{H}_{2} \mathrm{O} \\
\mathrm{CO}+\frac{1}{2} \mathrm{O}_{2} \rightarrow \mathrm{CO}_{2}
\end{gathered}
$$


All these reactions are detrimental for the fuel cell operation, because reducing gases are not electrochemically oxidized. Indeed, the main whished reaction is the electrochemical oxidation of hydrogen Eq.(5).

$$
\mathrm{H}_{2}+\mathrm{O}^{2-} \rightarrow \mathrm{H}_{2} \mathrm{O}+2 \mathrm{e}^{-}
$$

Some authors presented various cells geometries or reactors [7, 11-14], trying to improve performances. Furthermore, a lot of hydrocarbons such as methane, ethane, propane, alcohol were tested [15-16]. Various $\mathrm{C}_{\mathrm{x}} \mathrm{H}_{\mathrm{y}} / \mathrm{O}_{2}$ ratios were also tested in order to increase performances [9]. These results generally show that the best compromise is observed for a ratio between partial and total oxidation of the hydrocarbon. For propane, it corresponds to $\mathrm{C}_{3} \mathrm{H}_{8} / \mathrm{O}_{2}$ ratio in the range $0.2-0.66$, respectively for total and partial oxidations.

Some authors also reported open circuit voltage (OCV) oscillations [10, 17], which are explained by oxidation Eq.(6) and reduction Eq.(7) cycles of the nickel, respectively by oxygen and hydrocarbon:

$$
\begin{gathered}
\mathrm{Ni}+\frac{1}{2} \mathrm{O}_{2} \rightarrow \mathrm{NiO} \\
\mathrm{C}_{x} \mathrm{H}_{y}+x \mathrm{NiO} \rightarrow x \mathrm{CO}+\frac{y}{2} \mathrm{H}_{2}+x \mathrm{Ni}
\end{gathered}
$$

Such OCV oscillations explained by $\mathrm{Ni} / \mathrm{NiO}$ redox cycle were also observed for some conventional dual-chamber SOFC [18]. In a previous paper dealing with SCFC, we have also studied the specific problem of anode possible re-oxidation depending on temperature and propane/oxygen ratio [19]. It was demonstrated that a minimum temperature, around 500- 
$550^{\circ} \mathrm{C}$ depending on $\mathrm{C}_{3} \mathrm{H}_{8} / \mathrm{O}_{2}$, is required to avoid nickel oxidation. However, even in conditions where anode redox cycles are not supposed to occur (stability of nickel), some oscillations phenomena during SCFC evaluation were observed.

Another phenomenon explaining voltage oscillations is carbon deposition and combustion, especially in conventional SOFC fed with hydrocarbon. Hydrocarbon cracking on Ni-based anode, thus in reducing conditions, is responsible of carbon nano filaments formation [20-21]. However, in single chamber conditions, redox conditions are rather different as both anode and cathodes are exposed to the air/hydrocarbon mixture.

Hence, in this paper, we focus our investigations in order to propose a mechanism explaining such oscillating behaviour observed for anode electrical conductivity and SCFCs OCV on the basis of catalytic, electrical and electrochemical characterizations.

\section{Experimental}

\subsection{Materials \& Fuel cell preparation}

Electrolyte supported cells were prepared using a commercial GDC powder $\left(\mathrm{Ce}_{0,9} \mathrm{Gd}_{0.1} \mathrm{O}_{1,95}\right)$ supplied by FuelCellMaterials ${ }^{\mathrm{TM}}$, with a specific surface area of $8 \mathrm{~m}^{2} \cdot \mathrm{g}^{-1}$ measured by nitrogen adsorption on Micromeritics ASAP 2000 equipment (BET method). Average particle size was checked by laser granulometry analysis (Malvern Mastersizer 2000) and showed three maxima at 1,5 and $110 \mu \mathrm{m}$. The powder was sieved at $100 \mu \mathrm{m}$ to remove the largest particles. GDC powder was pressed into pellets and sintered with the following thermal treatment: $1200^{\circ} \mathrm{C}$ during 6 hours, then $1350^{\circ} \mathrm{C}$ during 4 hours. The final pellets have a diameter of $19 \mathrm{~mm}$, are $1.5 \mathrm{~mm}$ thick and present $94 \%$ relative density. 
$\mathrm{NiO}$ powder was supplied by Sigma-Aldrich ${ }^{\mathrm{TM}}$, and had a specific surface area of $5 \mathrm{~m}^{2} \cdot \mathrm{g}^{-1}$. Laser granulometry analysis revealed a very broad particle size distribution with various maxima, the most important being at 4 and $500 \mu \mathrm{m}$. To lower the average $\mathrm{NiO}$ particle sizes, a grinding procedure has been applied using a planetary ball mill (stainless steel balls) at 180 rpm for $30 \mathrm{~min}$. X-ray photoemission spectroscopy analyses after treatment did not show any pollution of the surface due to grinding. Laser granulometry analysis shows that all the agglomerates have been broken at sizes smaller than $100 \mu \mathrm{m}$.

The anode was prepared using $60 \%$ wt. of $\mathrm{NiO}$ and $40 \%$ wt. of GDC powders. Commercial binder and solvent (supplied by ESL ${ }^{\mathrm{TM}}$ ) were used to prepare an ink which was mixed and homogenised with an UltraTurrax ${ }^{\mathrm{TM}}$ for $20 \mathrm{~min}$. The ink was deposited using screen-printing technology (Aurel ${ }^{\mathrm{TM}}$ device) on one side of the electrolyte. Samples were treated at $130^{\circ} \mathrm{C}$ for 15 min to dry the ink. Five successive deposition-drying steps led to a $25 \mu \mathrm{m}$ thickness anode after a final annealing procedure at $1200^{\circ} \mathrm{C}$ during 2 hours.

For fuel cells preparation, a BSCF $\left(\mathrm{Ba}_{0.5} \mathrm{Sr}_{0.5} \mathrm{Co}_{0.8} \mathrm{Fe}_{0.2} \mathrm{O}_{3-\delta}\right)$ cathode was deposited on the opposite side of the electrolyte. The powder was supplied by IRCELYON laboratory and showed a specific surface area of $2 \mathrm{~m}^{2} \cdot \mathrm{g}^{-1}$. Laser granulometry analysis showed an average particle size of $10 \mu \mathrm{m}$. An ink was prepared using the same binders as for the anode layer. The cathode layer was annealed at $950^{\circ} \mathrm{C}$ for 2 hours. Finally, a gold commercial ink (ESL $\left.{ }^{\mathrm{TM}}\right)$ was used in order to deposit a collector on the surface of the cathode, and annealed at $950^{\circ} \mathrm{C}$ for 2 hours. A photograph of the obtained cell is presented in figure 1.

Figure 2 shows the cermet anode and cathode microstructures. One can see that both layers have a homogeneous thickness, around $25 \mu \mathrm{m}$ for the anode (Fig. 2a) and $40 \mu \mathrm{m}$ for the 
cathode (Fig. 2b). The two layers are porous, which is required for gas diffusion. As the objective of the present study was to investigate oscillatory phenomena occurring at anode side, the cathode microstructure was not optimized. Figure $2 b$ shows that the cathode may delaminate from the GDC electrolyte. For further studies, this problem was solved by using a 30/70 wt \% GDC/BSCF cathode [22].

\subsection{Electrical measurements}

Anode conductivity measurements were performed using in situ Van der Pauw method [23]. Four probes (using gold wires) were placed at the edges of the anode layer deposited on the GDC pellet. Wires were stuck to the sample with a platinum paste. Attention was given to minimize the platinum quantity and thus the contact size, both to reduce the platinum catalytic effect and also to minimize the measurement error according to Van der Pauw criteria.

Fuel Cells were tested under two different $\mathrm{C}_{3} \mathrm{H}_{8}: \mathrm{O}_{2}: \mathrm{N}_{2}$ atmospheres, namely (5:5:90) and (4:6:90) for comparison (vol. \% composition). For simplification, these atmospheres are named 5/5 and 4/6 ratios respectively. The total gas flow was 10 1/h. The 4/6 (0.66) ratio corresponds to the stoichiometric amounts for the partial oxidation. The other one (5/5) has a richer $\mathrm{C}_{3} \mathrm{H}_{8}$ quantity. These ratios were chosen because they correspond to the best catalytic activity towards propane conversion, determined from a previous study, concerning the anode stability under various $\mathrm{C}_{3} \mathrm{H}_{8} / \mathrm{O}_{2}$ mixtures [19]. A third ratio, 3/7 (3:7:90) has been investigated, but it led to anodes degradation; hence, it will not be presented. Conductivity and OCV were measured using a Keithley 2600C Sourcemeter.

The SCFC test bench is composed of a quartz tube which is inserted inside a tubular furnace. The sample holder is a long hollow tube. The extremity of this one has been cut to create a 
holder for the sample, as shown in figure 3. Gas and wires come from the inside of the tube. The gas flows in parallel directions to both cathode (down-side) and anode (up-side).

\subsection{Thermo-Programmed oxidation (TPO)}

The objective of TPO experiments is to detect possible carbon deposition on the anode during it's running in SCFC conditions.

A catalytic test bench, consisting of a quartz tube, an alumina protected thermocouple (close to the sample) and a furnace was used to perform the TPO study. $10 \mathrm{wt} \%$ of nickel oxide powder was mixed with $\alpha$-alumina (Alpha-Aesar ${ }^{\mathrm{TM}}$ ), reduced with hydrogen and then treated during two hours at $580^{\circ} \mathrm{C}$ with oxygen/propane mixture (either $5 / 5$ or $4 / 6$ ratios). After cooling under argon, samples were placed into a $1 \% \mathrm{O}_{2}$ containing atmosphere (balanced with argon) at $101 \cdot \mathrm{h}^{-1}$. A $2^{\circ} \mathrm{C} / \mathrm{min}$ ramp temperature was applied and a mass spectrometer (Balzers, OMNISTAR) was used to monitor the outlet gas concentrations, especially by measuring the mass numbers $(\mathrm{m} / \mathrm{z}) 44$ and 28 , in order to identify respectively $\mathrm{CO}_{2}$ or $\mathrm{CO}$ production.

\section{Results}

\subsection{Characterization of SCFC}

The as-prepared fuel-cells, more specifically the anode, need to be reduced before the tests. However, BSCF is known to be unstable under reducing environment such as $\mathrm{H}_{2}$ atmospheres [24-25]. This is why different tests were made in a previous study [24] using thermogravimetry analysis to find the best compromise for this step. In this case, it has been determined that directly injecting a $\mathrm{C}_{3} \mathrm{H}_{8} / \mathrm{O}_{2}$ mixture on the cermet was not sufficient to reduce nickel oxide. So we decided to use $\mathrm{H}_{2}$ for a short time ( $2 \mathrm{~min}$ ) to initiate the reduction at $580^{\circ} \mathrm{C}$. After this step, the complete reduction was achieved by the $\mathrm{C}_{3} \mathrm{H}_{8} / \mathrm{O}_{2}$ mixture (either 
$5 / 5$ or $4 / 6$ ratios). This treatment was performed in situ, so it was possible to monitor the OCV during the reduction. An example is represented in figure 4 for the $6 / 4$ ratio. It is possible to see that nearly two minutes after the $\mathrm{C}_{3} \mathrm{H}_{8} / \mathrm{O}_{2}$ introduction, the OCV rises suddenly up to 0.95 $\mathrm{V}$ and progressively stabilizes at $0.94 \mathrm{~V}$. This proves that nickel is reduced and that only few minutes are necessary to stabilize the cell.

Following the initialization treatment at $580^{\circ} \mathrm{C}$, OCV measurements were done for the SCFC under $4 / 6$ and $5 / 5 \mathrm{C}_{3} \mathrm{H}_{8} / \mathrm{O}_{2}$ ratios, at different temperatures. Results can be seen in figure $5 \mathrm{a}$ and $5 \mathrm{~b}$ respectively.

Concerning the $4 / 6$ ratio, it can be seen that OCV decreases with increasing temperature. Effectively, the value stabilizes at $0.92 \mathrm{~V}$ at $545^{\circ} \mathrm{C}$ and decreases to $0.895 \mathrm{~V}$ at $575^{\circ} \mathrm{C}$. This unexpected OCV variation in regards of ohmic loss decrease with higher temperature is explained by local changes of the oxygen partial pressure at the electrodes. In particular, , catalytic activity of BSCF cathode for propane conversion strongly increases in this temperature range, leading to lower oxygen activity gradient between anode and cathode [24]. After temperature stabilization at $575^{\circ} \mathrm{C}$, it appears that the OCV remains stable, with only small oscillations of around $2 \mathrm{mV}$ of amplitude.

On the contrary, the cell tested with the $5 / 5$ ratio has an opposite behaviour (figure $5 \mathrm{~b}$ ). OCV decreases from $0,896 \mathrm{~V}$ at $580^{\circ} \mathrm{C}$ to $0.87-0.88 \mathrm{~V}$ at $550^{\circ} \mathrm{C}$. At $570^{\circ} \mathrm{C}$, the voltage starts to oscillate. As the temperature decreases, the oscillation amplitude increases. At $550^{\circ} \mathrm{C}$, this oscillating amplitude is around $30 \mathrm{mV}$, and remains constant.

Isothermal tests at $565^{\circ} \mathrm{C}$ were reproduced in order to check previous behaviour for both $\mathrm{C}_{3} \mathrm{H}_{8} / \mathrm{O}_{2}$ ratios (figure 6). Initial OCV value is a little higher $(0.935 \mathrm{~V})$ but remains in the same range than the one measured before. The cell under a 4/6 ratio mixture keeps a nearly constant OCV value with very small oscillations with an amplitude lower than $5 \mathrm{mV}$. By 
contrast, the OCV of the cell under the $5 / 5$ ratio decreases to $0.9 \mathrm{~V}$, and an oscillating behaviour takes place, as shown before in fig. $5 \mathrm{~b}$, with an amplitude close to $20 \mathrm{mV}$.

Since these observations may be the consequence of different phenomena, both fuel cells were observed by Scanning Electron Microscopy. No differences were seen on the cathode side. On the contrary, the anode microstructure is different, as shown in figure 7.

Initially, the anode microstructure is a porous homogeneous mixture of $\mathrm{Ni}$ and CGO grains (figure 7a). After treatment at the $4 / 6$ ratio (figure $7 b$ ), the microstructure is similar, but some nanofibers are visible. They partially cover the anode surface. The same phenomenon is observed for the fuel cell tested with the $5 / 5$ ratio (figure $7 \mathrm{c}$ ), but nanofiber quantity is much more important, and they completely cover the anode surface. From the literature, it is expected that these nanofibers are carbon nanotubes resulting from propane cracking due the nickel catalytic activity $[20,21,26]$.

To confirm these observations, TPO measurements were performed over nickel powder as explained in experimental part. It was checked that no significant $\mathrm{CO}_{2}$ or $\mathrm{CO}$ evolving was detected with a nickel-free (only alumina) sample. For nickel samples, no peak were observed for signal $\mathrm{m} / \mathrm{z}=28$, corresponding to $\mathrm{CO}$ production.. On the contrary, different observations can be done for signal $\mathrm{m} / \mathrm{z}=44\left(\mathrm{CO}_{2}\right.$ production). Effectively, a production of $\mathrm{CO}_{2}$ is observed for the two samples in the range $350-600^{\circ} \mathrm{C}$ (figure 8 ). Even if this will not be discussed hereafter, the measured signal indicates that at least two different carbon species are present. Effectively, two different peaks can be observed for the samples. The maximum of the first one is at $440^{\circ} \mathrm{C}$ and the second one around $520^{\circ} \mathrm{C}$. Integration of the total $\mathrm{CO}_{2}$ peak observed in this temperature range leads to values of $1.37 \times 10^{-10}$ and $3.56 \times 10^{-10}$ (a.u.) for $4 / 6$ and $5 / 5$ ratios respectively. This result confirm that carbon deposition is much more important in the case of the $5 / 5$ ratio. This is in good agreement with the previously observed SEM 
microstructures, because the carbon nanofibers are much more numerous on the anode surface for the $5 / 5$ tested ratio.

\subsection{Electrical conductivity measurement}

As the carbon is a conducting material, and to prove that the oscillating behaviour previously observed is a consequence of the carbon nanowires presence, Van der Pauw conductivity measurements were done over the cermet anodes. To avoid the cathode influence, the cells were only composed of an electrolyte-supported anode, as described in experimental section.

Van der Pauw measurement method is usually used for arbitrary shape samples, and one of the conditions is to consider that the sample is dense. Since our cermet is porous, the measured conductivity is probably affected by the porosity and probably do not correspond to the real one. So, we use this method for comparison between samples, by considering for reference, reduced anode in hydrogen before exposure to propane/oxygen mixture. Hence, we are sure that the reference is not polluted by carbon deposition. So, conductivity higher than the reference one indicates a carbon deposition, and a lower one corresponds to nickel oxidation [19].

Directly after $\mathrm{H}_{2}$ reduction on the prepared anode cermet, the conductivity was measured as a function of time. Results are shown in figure 9. The obtained value is very stable and about $700{\mathrm{~S} . \mathrm{cm}^{-1}}^{-1}$ which will constitute the reference value for a reduced cermet.

Results concerning 4/6 and 5/5 ratio with varying temperature are presented respectively in figures 10 and 11. 
For 4/6 ratio (Fig. 10), after an initial stabilization time under gas (not seen in the figure), the value reaches $860 \mathrm{~S} . c m^{-1}$ which is higher than the reference one $\left(700 \mathrm{~S} . \mathrm{cm}^{-1}\right)$. It progressively

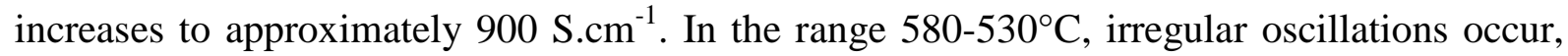
with increasing amplitude as temperature is decreasing. Amplitudes higher than $100 \mathrm{~S} . \mathrm{cm}^{-1}$ are visible at $530^{\circ} \mathrm{C}$. At temperature lower than $530^{\circ} \mathrm{C}$, the cermet starts to oxidize, as proved by the sudden decrease of the conductivity, and in agreement with our previous study [19].

For 5/5 ratio (figure 11), the initial value is much higher than in the previous case: $1100{\mathrm{~S} . \mathrm{cm}^{-}}^{-}$ ${ }^{1}$. This one remains stable between $555^{\circ} \mathrm{C}$ and $535^{\circ} \mathrm{C}$. Below this temperature, the electrical conductivity starts to oscillate. As observed for the 4/6 ratio, the oscillation amplitude is increasing when the temperature is decreasing. The electrical conductivity progressively drops

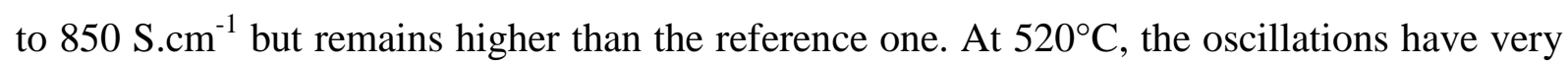
high amplitude in the range $850-1050{\mathrm{~S} . \mathrm{cm}^{-1}}^{-}$. Furthermore, the temperature also starts to oscillate with variations of $2-3^{\circ} \mathrm{C}$. Below this temperature, the electrical conductivity drops drastically, corresponding to the nickel oxidation.

To check if these oscillations are reversible, the temperature was increased from $510^{\circ} \mathrm{C}$ up to $535^{\circ} \mathrm{C}$ in the continuity of previous test. . This resulting graph (figure 12) shows that just after the temperature increase, the electrical conductivity comes back to $1000{\mathrm{~S} . \mathrm{cm}^{-1}}^{-1}$ This means that the nickel oxide is reduced again and already covered with carbon. After stabilization of the temperature, the conductivity starts again to oscillate.

Sample observation after test. (figure 13). clearly shows the carbon deposit at the surface of the cermet (black appearance). The grey appearance around the Pt paste corresponds probably to particular phenomena enhanced by the platinum (used as sticking paste) catalytic activity. In the centre of the sample, it is possible to observe arches: such structure corresponds to "space structures" related to oscillating reaction mechanisms which will be discussed hereafter. 


\section{Discussions}

\subsection{Oscillations origins}

All previous results are used to explain phenomena occurring in the anode. We have shown throughout this paper that some oscillations occur especially in the range $560-510^{\circ} \mathrm{C}$. They are pointed out by both OCV and conductivity measurements on the anode, with same type of variations depending on temperature and $\mathrm{C}_{3} \mathrm{H}_{8} / \mathrm{O}_{2}$ ratio. This proves that the oscillations origin come from the anode, as no cathode is present for Van der Pauw conductivity measurement. They are much more important for the 5/5 ratio. We have also shown that if the conductivity variations are high enough, the temperature starts to oscillate (Fig. 11) with an identical frequency, leading to space structures of the carbon inside the anode (Fig. 13).

In the literature, two types of oscillating behaviours have been presented for SCFC or Ni containing systems:

The first one has been attributed to the instability of nickel (redox cycles) in the presence of a high oxygen partial pressure $[10,17-18 ; 27-29]$. Considering this hypothesis and our

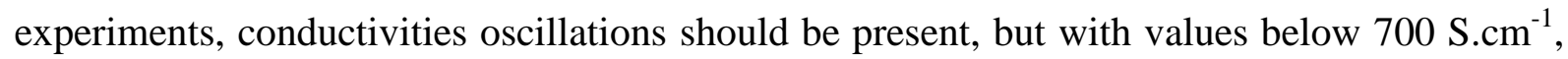
measured for reduced anode (Fig. 9). Since the measurements shows conductivities values up

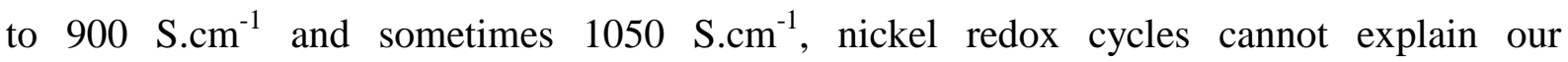
observations.

The second one is generally observed for co-planar SCFC. In this configuration, where the anode is on the same side as the cathode, the gap between the two electrodes is a determining factor for the performances. By reducing this gap (miniaturization), it is expected to obtain better performances [13]. However, it is observed that below a critical gap, the OCV becomes 
unstable due to the proximity of the anode and the cathode [30]. Then, oscillating phenomena are generally explained by the high oxygen partial pressure gradient between the electrodes. As all fuel-cells tested in the present study are in an opposite side configuration, and considering that the electrolyte is thick enough $(1.5 \mathrm{~mm}, 94 \%$ relative density) to avoid gas diffusion in the electrolyte pores, this possibility cannot explain the observations made here.

The only way to explain the observed oscillating behaviour is to consider carbon deposition/oxidation cycles. Effectively, high conductivity values obtained (900-1100 S.cm ${ }^{-1}$ ) during measurements under $\mathrm{C}_{3} \mathrm{H}_{8} / \mathrm{O}_{2}$ mixtures prove that carbon is present, and this was confirmed by SEM observations (Fig. 7).

To support this hypothesis, it is possible to consider thermal effects and temperature oscillations (Fig. 11). The sudden rise of the electrical conductivity (at experimental time 95 min, Fig. 11) is correlated to a drop of the temperature $\left(\sim 2^{\circ} \mathrm{C}\right)$ indicating an endothermic process. Effectively, all the reactions involving the propane decomposition to form carbon atoms are endothermic, as for example reaction Eq.(8):

$$
\mathrm{C}_{3} \mathrm{H}_{8} \rightarrow 3 \mathrm{C}+4 \mathrm{H}_{2}
$$

$\Delta \mathrm{H}^{\circ}\left(550^{\circ} \mathrm{C}\right)=125 \mathrm{~kJ} \cdot \mathrm{mol}^{-1}$

This reaction can explain the conductivity increase due to carbon formation and the momentary temperature decrease due to endothermic effect.

On the contrary, conductivities drops can be explained by the oxidation of carbon nanowires Eq. (9). TPO measurements have shown that it takes place between 350 and $600^{\circ} \mathrm{C}$ (Fig. 8), 


$$
\mathrm{C}+\mathrm{O}_{2} \rightarrow \mathrm{CO}_{2}
$$

$\Delta \mathrm{H}^{\circ}\left(550^{\circ} \mathrm{C}\right)=-394 \mathrm{~kJ} \cdot \mathrm{mol}^{-1}$

This last reaction which is exothermic can explain both oscillating behaviour of OCV and of conductivity. Effectively, OCV value is directly dependant on the oxygen partial pressure at the anode. So, local oxygen consumption increases the OCV value. Furthermore, it is possible to see also in figure 11 that when the conductivity is decreasing during an oscillation, the temperature is rising (around $2^{\circ} \mathrm{C}$ ). This is in agreement with the exothermic effect of Eq. (9).

As a conclusion, such a redox mechanism based on carbon formation and oxidation can explain both OCV and anode conductivity oscillation.

\subsection{Mechanism proposition}

To go further with the proposed mechanism, leading to formation of space structure of carbon, one can examine the required conditions of oscillation phenomena. Glansdorff and Prigogine [31] have studied oscillating behaviours and found out that this type of cycling reactions are generally obtained for systems which are far from thermodynamic equilibrium. To be possible, they need common requirements such as:

- An autocatalytic effect, illustrated by reaction Eq. (10)

$$
A+X \rightarrow 2 X
$$

- The compound involved in the autocatalytic reaction (X) must act as a reactant in another reaction Eq. (11)

$$
X+Y \rightarrow P
$$


Moreover, for heterogeneous systems, the system can present a space periodicity named "dissipative space structure". If this space structure appears, then the diffusion of one species is involved inside the mechanism.

In our study, the autocatalytic effect is difficult to highlight because it would need further catalytic experiments.. However, propane is known to crack on nickel, forming carbon and hydrogen (Eq. 8). It is possible that deposited carbon participates to the following autocatalytic effect (Eq.12).

$$
\mathrm{C}_{3} \mathrm{H}_{8}+\mathrm{C} \rightarrow 4 \mathrm{C}+4 \mathrm{H}_{2}
$$

Then, carbon acts as " $\mathrm{X}$ " species involved in the autocatalytic reaction (Eq.10) and is also reactant in carbon oxidation reaction Eq.(9). Furthermore, the mechanism is supported by explanation of carbon nanofilament formation in the literature. Carbon is deposited from a carbon source (hydrocarbon) on a metal particle ( $\mathrm{Ni}$ ) and then dissolves in the bulk of the particle; then it continues to precipitate as a fiber at the surface of this considered particle [21].

Finally, as described previously, we have observed dissipative spaces structures of carbon on the anode. So, all hypothesis and observations for explaining oscillations are consistent with cycling mechanism of carbon formation and oxidation.

\section{$\underline{\text { 5. Conclusions }}$}

During tests of a single chamber fuel cell under different $\mathrm{C}_{3} \mathrm{H}_{8} / \mathrm{O}_{2}$ atmospheres, oscillations of both OCV and anode conductivity were observed. SEM observations and TPO experiments, as well as high conductivity values allowed us to conclude that carbon formation and 
oxidation take place on the anode in our experimental conditions. Observations of dissipative space structures of carbon deposit lead to propose an oscillating mechanism involving carbon redox cycles.

\section{References}

[1] J. Wu, X. Liu, J. Mat. Science Tech. 2010, 26 (4), 293.

[2] R. Bove, S. Ubertini, J. Power Sources 2006, 159(1), 543.

[3] G.A. Tompsett, C. Finnerty, K. Kendall, T. Alston, N.M. Sammes, J. Power Sources 2000, $86(1-2), 376$.

[4] M.J. Pascual, A. Guillet, A. Durán, J. Power Sources 2007, 169 (1), 40.

[5] T. Hibino, H. Irahawa, Chem. Lett. 1993, 1131.

[6] T. Hibino, K. Asano, H. Irahawa, Chem. Lett. 1994, 485.

[7] M. Yano, A. Tomita, M. Sano, T.Hibino, Solid-State Ionics 2007, 177, 3351.

[8] M. Kuhn, T. Napporn, Energies 2010, 3(1), 57.

[9] B. Morel, R. Roberge, S. Savoie, T. Napporn, M. Meunier, Appl. Cata. A : Gen. 2007, $323,181$.

[10] X. Jacques-Bedard, T. Napporn, R. Roberge, M. Meunier, J. Power Sources 2006, 153(1), 108.

[11] Z. Shao, C. Kwak, S.M. Haile, Solid-State Ionics 2004, 175 (1-4), 39.

[12] T.W. Napporn, X. Jacques-Bedard, F. Morin, M. Meunier, J. Electrochem Soc. 2004, 151(12), A2088.

[13] B.E. Buergler, M. Oshsner, S. Vuillemin, L.J. Gauckler, J. Power Sources 2007, 171, 310. 
[14] T. Hibino, A. Hashimoto, M. Yano, M. Suzuki, S. Yoshida, M. Sano, J. Electrochem. Soc. 2002, 149(2), A133.

[15]T. Hibino, A. Hashimoto, T. Inoue, J. Tokuno, S. Yoshida, M. Sano, J. Electrochem. Soc. 2000, 147(8), 2888.

[16] T. Hibino, A. Hashimoto, T. Inoue, J. Tokuno, S. Yoshida, M. Sano et al., J. Electrochem. Soc. 2001, 148, A544.

[17] Z. Wang, Z. Lü, B. Wei, K. Chen, X. Huang, W. Pan, W. Su et al., Electrochimica acta 2011, 56, 6688.

[18] I.D. Kellogg, U. O. Koylu, V. Petrovsky, F. Dogan, International Journal of hydrogen energy 2009, 34, 5138.

[19] G. Gadacz, S. Udroiu, J.P. Viricelle, C. Pijolat, and M. Pijolat , J. Electrochem. Soc. 2010, 157(8), B1180.

[20] A. Atkinson, S. Barnett, R.J. Gorte, J.T.S. Irvin, A.J. Mc Evoy, M. B. Mogensen, S. Singhal, J.M. Vohs, Nature Materials 2004, 3(1), 17.

[21] S.McIntosh and R.J. Gorte, Chemical reviews 2004, 104, 4845.

[22] D. Rembelski, JP. Viricelle, L. Combemale, M. Rieu, Fuel Cells 2012, 12(2), 256.

[23] L.J. Van der Pauw, Philips Research Reports 1958, 13(1), 1.

[24] J.-P. Viricelle, S. Udroiu, G. Gadacz, M. Pijolat, C. Pijolat, Fuel Cells 2010, 10(4), 683.

[25] W. Zhou, R. Ran, Z. Shao, J. Power Sources 2009, 192(2), 231.

[26] Z. j. Sui , J.h. Zhou, Y.c. Dai, W.k. Yuan, Catalysis Today 2005, 106, 90.

[27] X.B. Ren, H.Y. Li, X.Y. Guo, Surface Science 2008, 602(1), 300.

[28] V. Y. Bychkov, Y. P. Tyulenin, V. N. Korchak, E. L. Aptekar, Appl. Cata. A : Gen. 2006, 304, 21.

[29] S. Savoie, T.W. Napporn, B. Morel, M. Meunier, R. Roberge J. Power Sources 2011,196, $3713 \mathrm{xx}()$. 
[30] M. Kuhn, T.W. Napporn, M. Meunier, S. Vengallatore, D. Therriault, J. Power Sources 2009, 194, 941.

[31] P. Glansdorff and I. Prigogine, Physica 1970, 46(3), 344. 


\section{Figure caption}

Figure 1: Photograph of a typical single-chamber fuel cell viewed from the cathode side, with gold collector

Figure 2: Anode (a) and cathode (b) microstructures observed by scanning electron microscopy on GDC support.

Figure 3: Schematic representation of the sample holder and positioning of the SCFC sample for electrical measurements

Figure 4: OCV measurement during initialization phase of the SCFC under $\mathrm{C}_{3} \mathrm{H}_{8} / \mathrm{O}_{2}$ mixture (6/4 ratio) at $580^{\circ} \mathrm{C}$.

Figure 5: OCV measurement as a function of the temperature, under $\mathrm{C}_{3} \mathrm{H}_{8} / \mathrm{O}_{2}$ ratio 4/6 (a) and $5 / 5(b)$

Figure 6: $\mathrm{OCV}$ variation with time, at $565^{\circ} \mathrm{C}$, under $4 / 6$ and $5 / 5 \mathrm{C}_{3} \mathrm{H}_{8} / \mathrm{O}_{2}$ ratios.

Figure 7: SEM of the initial anode fuel cell (a), after tests at $565^{\circ} \mathrm{C}$ under $4 / 6$ (b) and $5 / 5$ (c) $\mathrm{C}_{3} \mathrm{H}_{8} / \mathrm{O}_{2}$ ratios.

Figure 8: TPO measurements on $\mathrm{Ni}$ powder tested with the $4 / 6$ and $5 / 5$ ratio; mass spectrometry signals $\mathrm{m} / \mathrm{z}=44$.

Figure 9: Electrical measurement of the cermet under hydrogen at $580^{\circ} \mathrm{C}$

Figure 10: Electrical conductivity measured as a function of time and temperature for the $4 / 6$ ratio.

Figure 11: Electrical conductivity measured as a function of the time and the temperature for the $5 / 5$ ratio.

Figure 12: Electrical conductivity measured as a function of the time and the temperature for the 5/5 ratio, after a first oxidation of the nickel. 
Figure 13: Anode layer appearance after electrical measurements (5/5 ratio). The wide array indicates positioning of the sample in regards of gas flow exposure. Thin arrays indicate space structures. 